\title{
ICCECIP 2021 International Scientific Conference
}

\author{
Tünde Anna KOVÁCS ${ }^{1}$, Zoltán NYIKES ${ }^{2}$ \\ ${ }^{1}$ Óbuda University, Budapest, Hungary \\ ${ }^{2}$ Milton Friedman University, Budapest, Hungary
}

\section{ICCECIP 2021}

The ICCECIP 2021 - 3rd International Conference on Central European Critical Infrastructure Protection was held this year on 15 th November. This year conference was the third after the 2019 and 2020 ones. This event as part of the Hungarian Science Festival was organized by the Bánki Donát Faculty of Mechanical and Safety Engineering of the Óbuda University, Milton Friedman University and Batthyány Lajos Foundation in a historical place of the Castle, in the Villa of Lónyai-Hatvany. The motto of this year's conference is "Kinetic and cyber tools in the critical infrastructure protection".

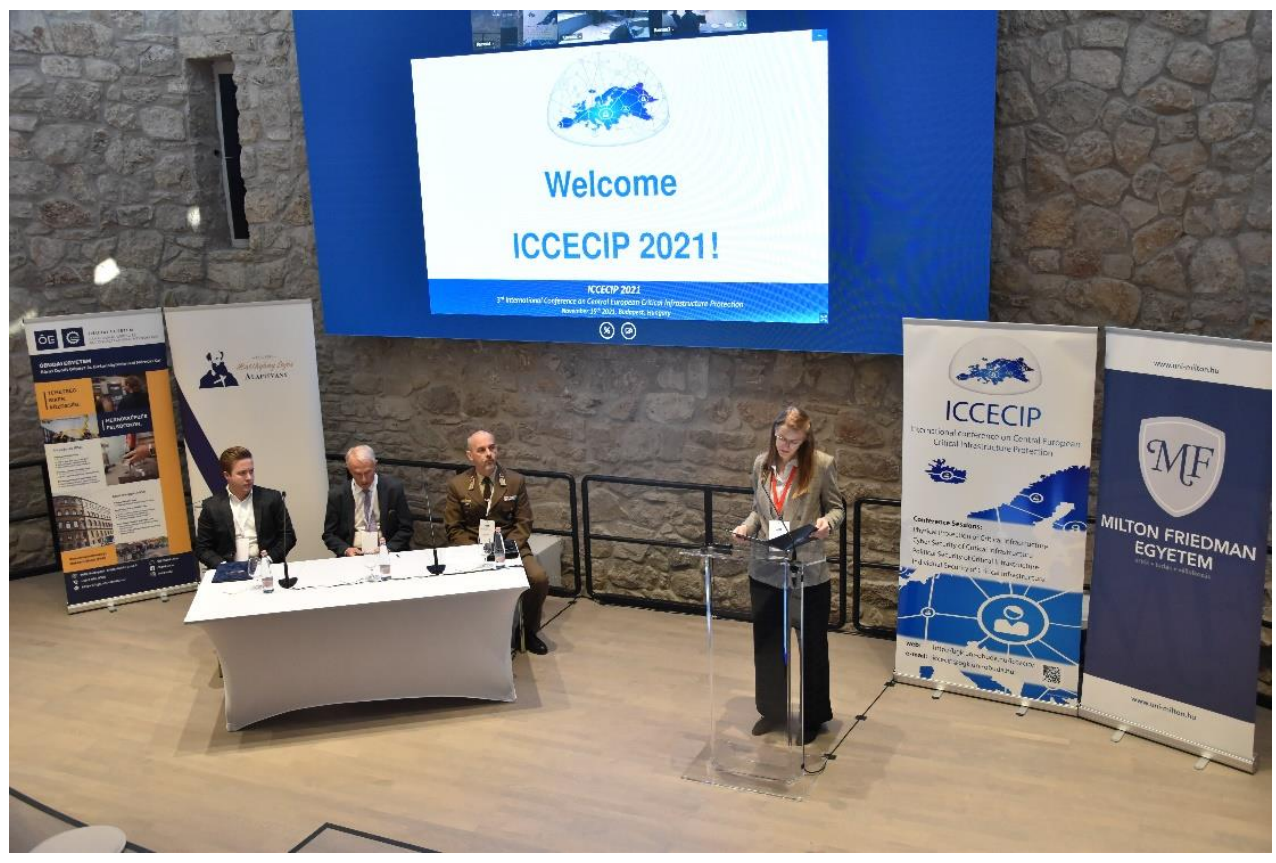

Fig. 1. Welcome ceremony

The conference chief patron in this year and also the years before was Szilárd Németh Deputy Minister of Ministry of Defence, Hungary. The conference scientific patron was Prof. Dr Miklós Maróth the President of the Eötvös Loránd Research Network who supported the conference series continuously in the last few years. The conference was organized in English, in 
a hybrid form in accordance with the recommendation of the COVID situation. In the place of the chief patron Dr Ferenc Attila Varga colonel, Head of Department of the MOD Department of Defense Administration, Hungary held a welcome speech in the opening ceremony. Dr Ferenc Attila Varga colonel, Head of Department of the MOD Department of Defense Administration, Hungary held a welcome speech in the opening ceremony and welcomed the participants of the conference, instead of the chief patron. Prof. Dr Zoltán Rajnai Honorary chair of the conference, dean of the Bánki Donát Faculty of Mechanical and Safety Engineering had greeted the conference participants in his opening remark. After it the rector of the Milton Friedman University, Dr János Perényi delivered his opening speech. The final remark of the opening ceremony was interpreted by István Pócza on behalf of the host, Batthyány Lajos Foundation.

The event was persisted by plenary speakers presentations. The first plenary speaker was Prof. Dr Alexis Rusinek Attaché of the French Embassy in Budapest. He was followed by Prof. Dr Tibor Kovács associate professor of Óbuda University and after by Dr Kostiantyn Afanasenko associate professor of the National University of Civil Defence of Ukraine, Ukraine and Dr Robert C. Castel the scientific associate of the Israel National Parks Authority, Israel. The final plenary speaker was Prof. Dr Kornélia Lazányi professor of Óbuda University, who closed the plenary session with her excellent speech.

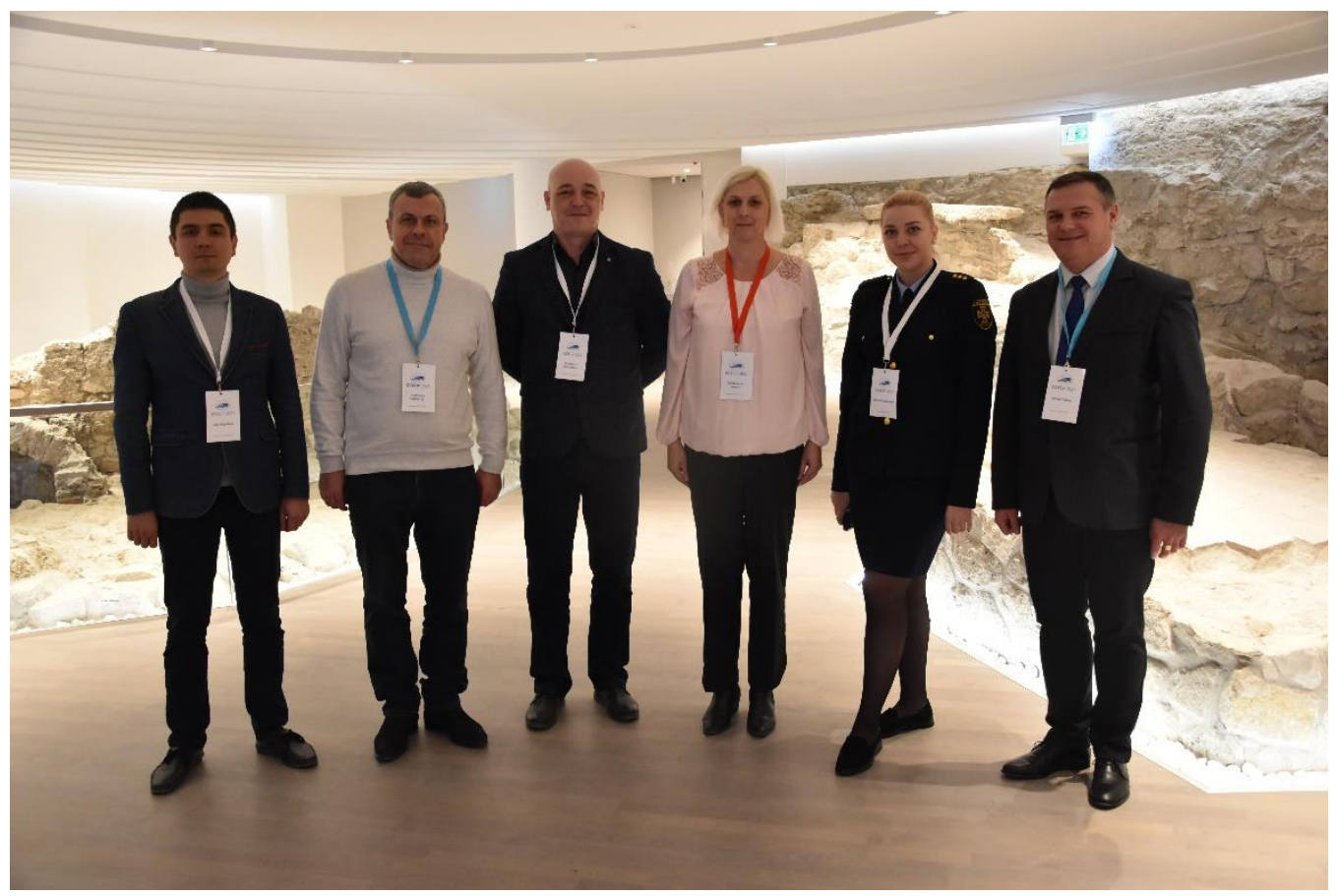

Fig. 2. Organizing commitee

This year during the one day conference was delivered 21 presentations included plenary speeches too, on Individual Security, Cyber Security, Physical Security and Political Security of Critical Infrastructure Protection. In the poster session, it was displayed several different research area results on eight posters. The success of the conference is confirmed by several foreign participants. Next to the Hungarian participants were from Poland, Albania, Bosna-Herceg, Serbia, Romania, Ukraine, Marokko, France, Iraq, Algerie, Syria, Izrael, China, speakers, represented on 16 universities and 3 associations. The scientific results of the conference speeches and posters will be published in article form in different journals, like Defence Review, Interior 
Review, Military Technique, National Security Review, Military Logistic, Közelítések, Safety and Security Sciences Review, Aeronautical Science Bulletins are Hungarian scientifical journals, also the Critical Infrastructure Protection Review and Cyber Security Review British scientifical journals, the Security Engineering of Anthropogenic Objects és Rzeczocnawce/Engineering Exper Polish scientifical journal, Transactions of the VSB Technical University of Ostrava Safety Engineering Series Bohemian scientifical Journal and the European Journal of Materials Science and Engineering Romanian scientifical Journal.

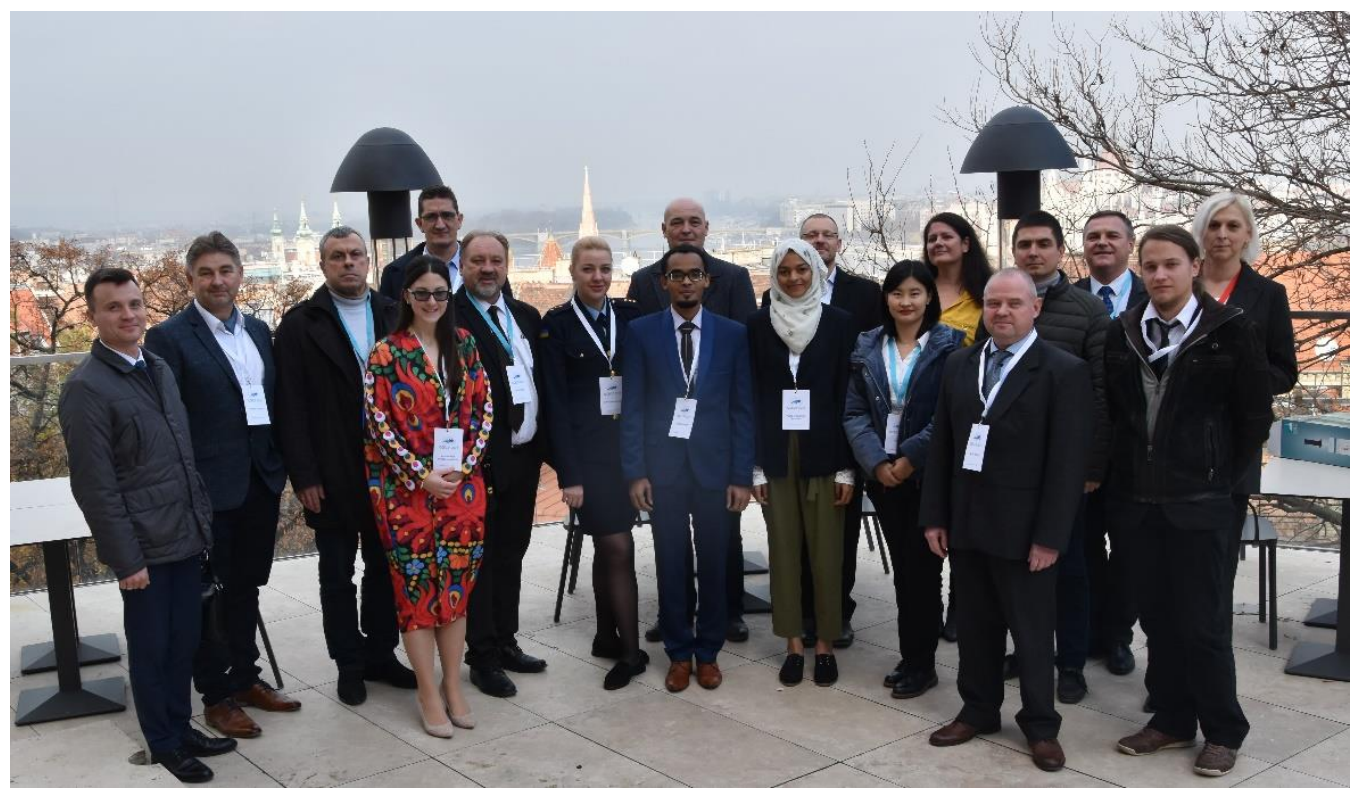

Fig. 3. Guest and participants

As part of the closing ceremony Prof Dr Zoltán Rajnai, dean of Bánki, Honorary chair of the conference in his closing speech told thanks for the speakers and poster presenters, the participants in the event and told thanks for the organizer group and told highlighted thanks for the organizing of the event for Dr Tunde Anna Kovacs chair of the international organization board, for Dr Zoltán Nyikes director of the international organization board and István Pócza the professional program director of the host.

The honorary chair in addition invited the participants for the fourth event, which will be held in November 2022, the ICCECIP 2022 as part of the conference series.

\section{Dr Tünde Anna Kovács}

Associate professor, chair of the international organization board

\section{Dr Zoltán Nyikes}

Associate professor, director of the international organization board 